\title{
PENGARUH EXPERIENTAL VALUE DAN PLACE FOOD IMAGE TERHADAP BEHAVIORAL INTENTION WISATA KULINER BANDUNG
}

\author{
Inad Wasa Nugroho \\ Siti Rahayu \\ Erna Andajani
}

Email: inadnugroho79@yahoo.co.id

Fakultas Bisnis dan Ekonomika, Universitas, Surabaya, Indonesia

\begin{abstract}
Every tourist has a different motivation. One type of tourism that is currently growing very rapidly is the culinary industry. This study is to determine the experiential value of tourists in shaping the place food image of the city of Bandung and influencing behavioral intention. This causal type of quantitative research analyzes data using the Structural Equation Model equation. The results of the study found evidence of all research hypotheses proved to have a positive and significant influence relationship.

Keywords: Bandung, Culinary, Tourism
\end{abstract}

\section{PENDAHULUAN}

Pariwisata saat ini sudah menjadi gaya hidup. Berwisata telah menjadi sebuah kebutuhan untuk mengurangi kejenuhan akan aktivitas sehari-hari. Berwisata juga dapat menunjukkan status sosial seseorang. Setiap wisatawan memiliki motivasi yang berbeda-beda akan perjalanan yang akan dilakukan.

Industri pariwisata merupakan sektor yang paling menjanjikan serta dapat menyentuh hingga ke level paling bawah masyarakat. Setiap tahun performa pariwisata Indonesia terus naik. Melalui branding Wonderful Indonesia, peringkat daya saing pariwisata Indonesia di dunia sendiri terus mengalami kenaikan, setelah melompat tajam dari ranking 70 pada 2013 menjadi ranking 50 pada 2015, indeks daya saing Indonesia kembali mengalami kenaikan 8 peringkat ke peringkat 42 pada 2017.

Branding Wonderful Indonesia didasarkan pada beberapa kenyataan tentang daya tarik dari pariwisata dan memiliki lima kriteria yaitu Wonderful Nature, Wonderful Culture, Wonderful People, Wonderful Food, Wonderful Value for Money.

Salah satu jenis wisata yang saat ini sedang berkembang sangat pesat yaitu Industri kuliner. Data dari Badan Ekonomi Kreatif (Bekraf) Republik Indonesia mencatat, subsektor kuliner berkontribusi 41,4 persen dari total kontribusi perekonomian kreatif Rp922 triliun pada 2016, jumlah tersebut merupakan yang paling tinggi dibandingkan 16 sub-sektor lain di Bekraf RI. Kuliner merupakan salah satu penopang di industri kreatif, dari 8,2 juta unit industri kreatif, 68 persen bergerak di industri kuliner (https://travel.kompas.com). 
Kegiatan makan mungkin tidak hanya bertujuan untuk mengenyangkan perut belaka. Makanan yang merupakan kebutuhan primer, saat ini juga bisa digunakan sebagai maupun sarana untuk berkumpul buat keluarga. Tempat hiburan bukan hanya taman, gunung dan pantai saja, akan tetapi restoran juga bisa dijadikan alternatif untuk mendapatkan kesenangan. Kuliner telah identik dengan gaya hidup (https://www.cnnindonesia.com).

Indonesia tidak hanya terkenal akan wisata alamnya, tetapi juga dengan kulinernya yang kaya akan rempah-rempah. Setiap daerah atau kota-kota di Indonesia memiliki kuliner yang berbeda dengan daerah lain dan ciri khas tersendiri.

Pemerintah Indonesia menjadikan pariwisata sebagai lini sektor utama, maka dari itu tidak hanya country branding saja yang dilakukan oleh pemerintah, akan tetapi branding daerah-daerah yang dianggap memiliki potensi pariwisata yang dapat membantu memasarkan brand Wonderful Indonesia. Ada sepuluh destinasi branding yang telah ditunjuk oleh pemerintah, salah satunya adalah Bandung (https://www.goodnewsfromindonesia.id).

Dengan logo Stuning Bandung: where the wonders of West Java, Bandung dimaknai sebagai titik awal bagi wisatawan untuk menemukan lebih banyak keindahan alam dan budaya yang ada di Jawa Barat. Branding ini diharapkan dapat membantu Wonderful Indonesia. Selain kampung wisata, Bandung dikenal sebagai kota jasa yang banyak menyediakan wisata hiburan dan MICE (Meeting, Incentive, Conventions, and Exhibitions). Bandung juga memiliki 10 museum, 280 tempat hiburan, 600 bangunan cagar budaya, 1200 cafe dan restoran, serta 20 taman kota tematik yang selalu ramai dikunjungi oleh wisatawan (http://www.pikiranrakyat.com).

Bandung sebagai objek studi ini karena Kementrian Pariwisata RI telah menetapkan tiga destinasi wisata kuliner, Bandung menempati urutan pertama, Joglosemar (Yogyakarta, Solo, Semarang) menempati urutan kedua, dan Bali menempati urutan ketiga (https://lifestyle.sindonews.com). Bandung yang sudah terdukung oleh 3A (Akses, Amenitas, Atraksi), merupakan destinasi wisata kuliner terfavorit dengan kekayaan kuliner tidak terbatas, disebut sebagai surga kuliner (http://ulinulin.com). Jumlah wisatawan domestik dan mancanegara periode 20122016 selalu mengalami kenaikan (Tabel 1).

Tabel 1 Pertumbuhan Wisatawan ke Bandung Periode 2012-2016

\begin{tabular}{cllcc}
\hline \multirow{2}{*}{ Tahun } & \multicolumn{2}{c}{ Wisatawan } & Jumlah & Pertumbuhan \\
\cline { 2 - 3 } & Mancanegara & Domestik & & \\
\hline 2012 & 1.905 .378 & 42.758 .063 & 44.663 .441 & \\
2013 & 1.794 .401 & 45.536 .179 & 47.330 .580 & $6 \%$ \\
2014 & 1.962 .639 & 47.992 .088 & 49.954 .727 & $6 \%$ \\
2015 & 2.027 .629 & 56.334 .706 & 58.362 .335 & $17 \%$ \\
2016 & 4.428 .094 & 58.728 .666 & 63.156 .760 & $8 \%$ \\
\hline
\end{tabular}

Sumber: https://jabar.bps.go.id

Bandung memiliki banyak sekali julukan, mulai dari kota kembang, Paris Van Java, hingga City of Heritage. British Council menjadikan Kota Bandung sebagai 
pilot project kota terkreatif se-Asia tenggara. UNESCO menyebutnya sebagai Creative City Network (UCCN) dalam bidang desain. Setelah itu, Bandung juga dijuluki sebagai Kota kuliner, ada banyak makanan dan minuman khas Bandung yang dapat dinikmati mulai dari makanan ringan hingga makanan berat (https://ngulon.com).

Rasanya ada yang kurang jika berkunjung ke Bandung tetapi tidak mencicipi kulinernya. Bandung sendiri terkenal akan wisata kulinernya sehingga Bandung merupakan salah satu kota yang ditetapkan sebagai destinasi wisata kuliner nasional (https://travel.kompas.com). Ada banyak sekali makanan dan minuman khas yang dapat dinikmati di Bandung, seperti seblak, mie kocok, surabi, tahu susu Lembang, batagor, wajit, pisang bolen, bajigur, dan masih banyak lagi.

Di Bandung terdapat beberapa tempat makan yang sangat ramai, sehingga pengunjung harus antri untuk dapat menikmati makanan yang ingin dibeli. Harga yang ditawarkan juga sangat bersahabat (http://www.angkutkoper.com).

Jika pernah mengunjungi Kota Bandung maka dapat dipastikan akan memiliki niat untuk berkunjung lagi, karena experiental value yang didapat akan mempengaruhi place food image bagi sebuah kota. Oliver (1980) menyatakan bahwa experiental value dapat membantu konsumen mengevaluasi kepuasan.

Tsai dan Wang (2016) melakukan studi juga di kota Tainan, Taiwan. Kota bersejarah yang terkenal dengan banyak pedagang kaki lima yang menjual makanan tradisional. Ditemukan bukti bahwa experiental value yang meliputi customer return on invesment, service excellence, aesthetic, playfulness memiliki pengaruh langsung terhadap place food image yang juga berpengaruh langsung pada behavioral intention.

Studi ini untuk mengetahui experiental value wisatawan dalam membentuk place food image kota Bandung dan mempengaruhi behavioral intention. Untuk mengetahui pengaruh customer return on invesment, service excellence, aesthetics, dan playfulness terhadap place food image kota Bandung. Selanjutnya, akan dianalisis pengaruh place food image kota Bandung terhadap behavioral intention wisatawan.

\section{METODE PENELITIAN}

Penelitian kuantitatif ini berjenis kausal, dengan tujuan utama untuk menguji adanya hubungan sebab akibat antar-variabel yang diteliti (Malhotra et al., 2007: 885) karena ingin menggambarkan penyebab dari suatu permasalahan yang sedang diteliti (Sekaran \& Bougie, 2010:110). Berdasarkan hasil penelitian kausal yang dilakukan maka akan ditemukan hubungan antar-variabel. Jenis penelitian kausal bertujuan untuk menentukan hubungan antara experiental value Bandung terhadap place food image yang akan mempengaruhi behavioral intention wisatawan.

Variabel eksogen studi ini yaitu Experiential value yang terdiri dari Customer return on Invesment (CROI), Service Excellence, Aesthetic, dan playfulness. Variabel endogen dalam penelitian ini yaitu place food image dan behavioral intention. 
Data diperoleh dari hasil survey yang dilakukan dengan cara menyebarkan kuisioner kepada para responden yang telah ditetapkan berdasarkan pada pendapat atau tanggapan responden yang pernah melakukan wisata kuliner di Bandung.

Sampel sebanyak 150 orang diambil secara non-probability sampling berjenis purposive sampling. Responden harus pernah melakukan perjalanan wisata kuliner di Bandung minimal satu kali dalam satu tahun terakhir dan pernah melakukan perjalanan wisata kuliner di Bandung.

Setelah uji validitas dan uji reabilitas, data diolah dengan menggunakan program Analysis of Moment Structures (AMOS) yang digunakan sebagai pendekatan umum analisis data dalam model persamaan Structural Equation Model (SEM).

\section{HASIL DAN PEMBAHASAN}

Uji validitas menunjukkan bahwa item-item pertanyaan dalam setiap dimensi kuisioner ini dapat dinyatakan valid dan dapat digunakan. Begitu pun, uji reliabilitas menunjukkan bahwa kuisioner dalam penelitian ini telah reliabel.

Pengamatan terhadap 150 responden menunjukkan bahwa 34\% laki-laki dan $66 \%$ perempuan dengan didominasi $48 \%$ berusia $18-30$ tahun dan $28 \%$ berusia $31-$ 40 tahun. Tingkat pendidikan responden terbanyak adalah S1 yakni sebesar $40 \%$ dan menunjukkan bahwa dari 150 responden terdapat 38 orang yang tingkat SMA/SMK/Sederajat sebanyak $25.33 \%$.

Secara keseluruhan rata-rata jawaban responden tentang customer return on investment, service excellence, aesthetics, playfulness, place food image, serta behavioral intention menunjukkan bahwa Bandung telah memenuhi harapan responden.

Analisis Confimatory Factor Analysis (CFA) menunjukkan bahwa model pengukuran layak dianalisis lebih lanjut karena sudah memenuhi kriteria yang disyaratkan Goodness of Fit (Gambar 1). 


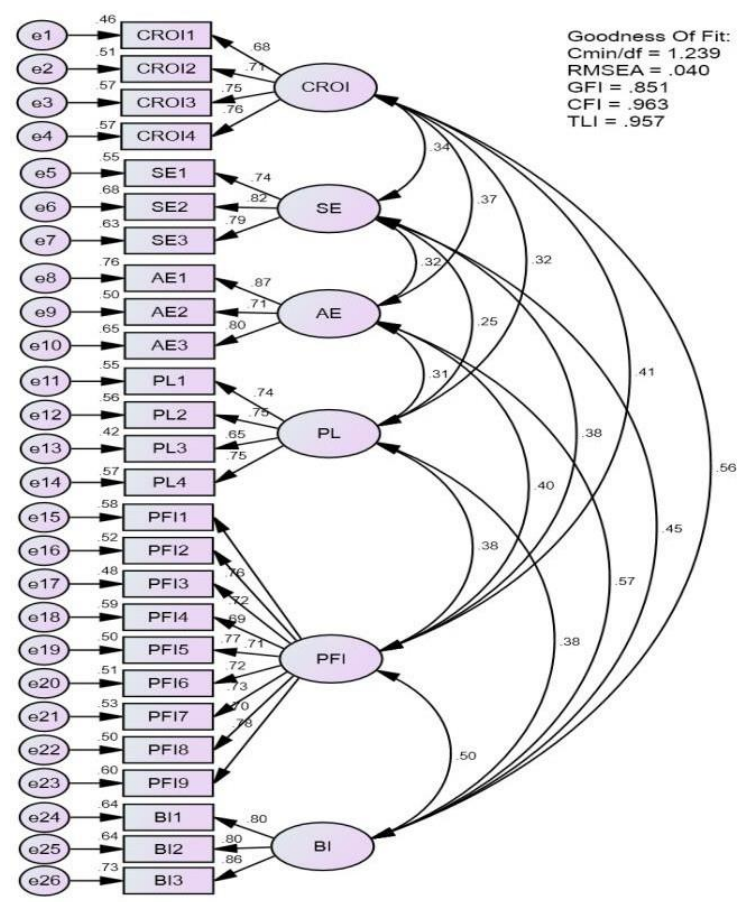

Gambar 1 Model Pengukuran

Analisis dengan program AMOS menunjukkan bahwa secara umum hasil evaluasi model struktural sudah menunjukkan kriteria yang baik. Ukuran goodness of fit sudah memenuhi kriteria yang ditetapkan, bisa digunakan untuk pengujian hipotesis penelitian (Gambar 2).

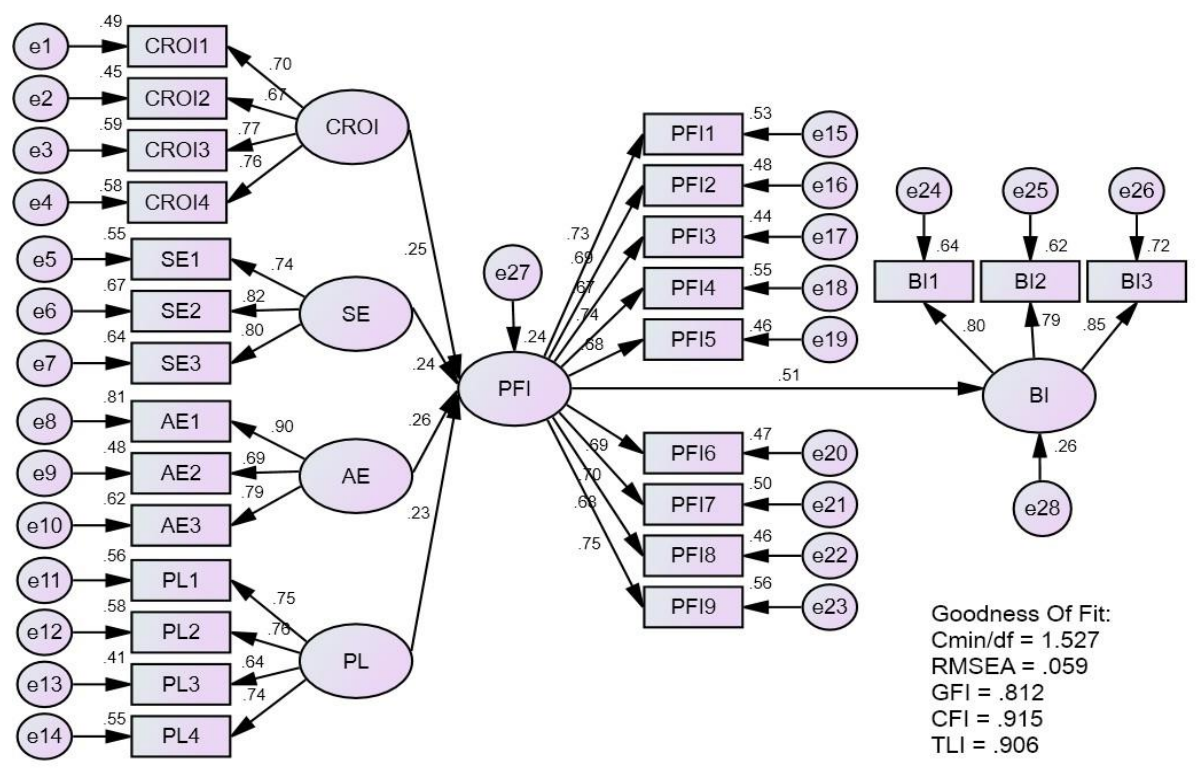

Gambar 2 Model Struktural 
Pengaruh antar variabel di Tabel 2 menunjukkan bahwa semua hipotesis penelitian terbukti memiliki hubungan pengaruh positif dan signifikan.

Tabel 2 Hasil Uji Hipotesis

\begin{tabular}{llccccc}
\hline \multicolumn{1}{c}{ Hipotesis } & $\begin{array}{c}\text { Std. } \\
\text { Estimate }\end{array}$ & S.E. & C.R. & P & Keterangan \\
\hline H1 & $\begin{array}{l}\text { Customer return on investment } \\
\rightarrow \text { Place Food Image }\end{array}$ & 0.253 & 0.101 & 2.579 & 0.010 & Terdukung \\
H2 & $\begin{array}{l}\text { Service excellence } \rightarrow \text { Place Food } \\
\text { Image }\end{array}$ & 0.237 & 0.089 & 2.486 & 0.013 & Terdukung \\
H3 & $\begin{array}{l}\text { Aesthetics } \rightarrow \text { Place Food Image } \\
\text { H4 }\end{array}$ & 0.262 & 0.069 & 2.820 & 0.005 & Terdukung \\
Playfulness $\rightarrow$ Place Food Image & 0.231 & 0.090 & 2.382 & 0.017 & Terdukung \\
H5 $\begin{array}{l}\text { Place Food Image } \rightarrow \text { Behavioral } \\
\text { Intention }\end{array}$ & 0.505 & 0.108 & 5.512 & $* * *$ & Terdukung \\
\hline
\end{tabular}

Customer return on invesment berpengaruh positif dan signifikan terhadap place food image Bandung, sesuai dengan Tsai dan Wang (2016) serta Masiero dan Nicolau (2012). Wisatawan akan membandingkan antara biaya dan kualitas makanan yang ada di sebuah destinasi wisata. Informasi diperoleh melalui word of mouth atau dari internet. Menurut persepsi wisatawan, Bandung merupakan kota yang memiliki makanan dengan harga terjangkau. Hanya dengan Rp8.500,wisatawan sudah dapat menikmati salah satu makanan yang terkenal di Bandung yaitu Batagor Ihsan.

Service excellence berpengaruh positif dan signifikan terhadap place food image, sejalan dengan Sekarrini et al. (2017). Keunggulan layanan yang dimiliki Bandung berdampak kepada citra dari restoran atau tempat makan. Hal ini sendiri disebabkan karena wisatawan yang berkunjung di Bandung merasakan keramahan dari para penjual makanan. Terdapat banyak tempat makan yang menawarkan makanan yang enak dan menggugah selera, seperti kampung daun dengan menu surabi, batagor, nasi liwet, nasi tembel dan masih banyak lagi.

Aesthetics berpengaruh positif dan signifikan terhadap place food image, sejalan dengan Sekarrini et al. (2017). Keindahan secara fisik lingkungan Bandung berdampak kepada citra dari restoran atau tempat makan. Saat ini, wisatawan mengunjungi restoran atau tempat makan tidak hanya sekedar ingin menikmati makanan saja, tetapi suasana dari tempat makan yang indah untuk berfoto lalu mengupload ke sosial media. Sebagai contoh, Taman Kardus Bandung mengusung konsep serba kardus dengan berbagai ornamen di dinding, kursi, dan meja makan dari karton berwarna coklat bertipe AA yang bisa menahan beban hingga $300 \mathrm{~kg}$.

Playfulness berpengaruh positif dan signifikan terhadap place food image, sejalan dengan Rangkuti \& Situmorang (2017). Responden merasa bahwa hiburan sebagai kenikmatan intrinsik yang dimiliki Bandung baik sehingga berdampak pada citra dari restoran atau tempat makan. Banyak tempat makan dengan konsep menyenangkan dan unik, misalkan Nanny's Pavilion Home dengan design interior vintage dan dekorasi yang artistik dan lucu berkonsep taman, perpustakaan, kamar tidur, kamar mandi, ruang main anak, dan ruang ibu menjahit.

Place food image berpengaruh positif dan signifikan terhadap behavioral intention, sesuai dengan Tsai dan Wang (2016). Responden setuju bahwa Bandung adalah kota yang cocok untuk berwisata kuliner, karena memiliki makanan yang 
beragam dan menggugah selera. Dimulai dari makanan khas hingga makanan dari luar negeri seperti Jepang hingga Amerika. Dengan demikian, Bandung merupakan kota yang menarik untuk dikunjungi lagi pada masa datang untuk berwisata kuliner.

\section{KESIMPULAN}

Terdapat pengaruh signifikan dari customer return on invesment terhadap place food image Bandung. Terdapat pengaruh signifikan dari service excellence terhadap place food image Bandung. Terdapat pengaruh signifikan dari aesthetics terhadap place food image Bandung. Terdapat pengaruh signifikan dari playfulness terhadap place food image Bandung. Terakhir, terdapat pengaruh signifikan dari place food image terhadap behavioral intention.

\section{DAFTAR PUSTAKA}

http://ulinulin.com/posts/10-kota-wisata-kuliner-terfavorit-di-iindonesia. Diakses pada tanggal 5 Oktober 2018.

http://www.pikiran-rakyat.com/bandung-raya/2017/09/14/stunning-bandungdorong-peningkatan-wisatawan-asing-ke-indonesia-409409. Diakses pada tanggal 30 Oktober 2018.

https://jabar.bps.go.id/statictable/2018/03/23/473/jumlah-wisatawanmancanegara-dan-domestik-di-provinsi-jawa-barat.html. Diakses pada tanggal 28 Oktober 2018.

https://lifestyle.sindonews.com/read/1296522/156/kemenpar-tetapkan-3-destinasisebagai-wisata-kuliner-1523291455. Diakses pada tanggal 2 Oktober 2018

https://www.goodnewsfromindonesia.id/2017/06/17/inilah-logo-baru-10-destinasiwisata-indonesia. Diakses pada tanggal 20 Oktober 2018.

Journal od destination Marketing and Management. https://travel.kompas.com/read/2014/12/24/164500827/Peluncuran.Wonderful.Ind

Malhotra, N., Budhwar, P., \& Prowse, P., 2007, Linking rewards to commitment: an empirical investigation of four $\mathrm{UK}$ call centres, The International Journal of Human Resource Management, Vol. 18 No. 12, pp. 2095-2128.

Masiero, L., \& Nicolau, J. L., 2012, Tourism market segmentation based on price sensitivity: Finding similar price preferences on tourism activities, Journal of

Oliver, R.L.,1980, A cognitive model of the antecedents and consequences of satisfaction decision, Journal of Marketing Research,17 (November), 460469.

onesia.dan.Pesona.Indonesia. Diakses pada tanggal 2 Oktober 2018

Rangkuti, A. M., \& Situmorang, S. H., 2017, Pengaruh Experiental value terhadap Place Food Branding dan Behavioral Intention pada Kuliner Kota Medan, Manajemen Eksistensi, Universitas Sumatra Utara.

Sekaran, U. \& Bougie, R., 2010, Research Method for Business: A Skill Building Approach. Edisi 5. John Wiley \& Sons, New York.

Sekarrini, N. L., Rahayu, S., \& Andajani, E., 2017, Pengaruh Experiential Value dan Place Food Image Yogyakarta Terhadap Behavioral Intention Wisatawan Domestik, Manajemen Layanan dan Pariwisata, Skripsi, Universitas Surabaya. Travel Research, 51(4), 426-435. 
Tsai, C.W., Wang, Y.C., 2016, Experiental value in Branding Food Tourism, 